\title{
- linguists
}

\section{IMPROVING READING COMPREHENSION AND SPEAKING PERFORMANCE OF THE EIGHTH GRADERS USING ICM}

\author{
EKO SAPUTRA \\ Akademi Keperawatan KESDAM II/ Sriwijaya \\ Ekosaputrawijaya452@gmail.com
}

DOI : http://dx.doi.org/10.29300/ling.v6i1.2933

\begin{abstract}
The aim of this experimental study was to investigate whether or not there were significant improvements in students' reading comprehension and speaking performance after being taught by using Instructional Conversation Method. This study also aimed to see the significant difference in reading and speaking achievements between the students who got the treatment and those who did not. Sixty eight eighth graders with the same reading level were selected as the sample and were divided equally into experimental and control groups. Pretest and posttest were given to both groups, but the treatment was only for the experimental group. The data obtained from reading comprehension and speaking pretest and posttests in both groups were analyzed by using paired and independent sample t-tests. The result showed that after the students were taught by using ICM there were significant improvements in their reading and speaking achievements. There were also significant differences in reading and speaking achievements between both groups. In conclusion, ICM could help students improve their reading comprehension and speaking performance.
\end{abstract}

Keywords: Reading comprehension, speaking performance, ICM

\section{INTRODUCTION}

Reading is a receptive skill that involves getting information and meaning, visual information, and written information. According to Konza (2006, p. 1), reading in English is an activity done by students to get information from many kinds of texts. Reading also means comprehending the written information. The phrase "reading comprehension" is defined as the process of making meaning from text. The purpose of it is to gain the picture of what is described in the text (Woolley, 2011, p. 15). This is in line with one of the main objectives stated in the Regulation Number 70, 2013 of teaching English reading at Junior High school in Indonesia, that is, to make students able to comprehend texts.

In addition to reading skill, the teaching of English reading skill in Indonesia is also focus on speaking skill. Based on the standard competence of English teaching as stated in curriculum 2013, students of SMP/MTs must be able to express, present, and describe what

How to cite this article: Saputra, E. (2020). Improving Reading Comprehension and Speaking Performance of the Eight Graders Using ICM. Linguists : Journal Of Linguistics and Language Teaching, 6(1), 89-100. doi:http://dx.doi.org/10.29300/ling.v6i1.2933 
have learned at school. English speaking holds a very significant place in language learning because through speech messages are conveyed.

Speaking is one of the important skills that is defined as an activity to express ideas orally. Richards and Renandya (2002, p. 204) state that effective oral communication requires the ability to use the language appropriately in social interactions that involve not only verbal communication, but also paralinguistic elements of speech such as pitch, stress, intonation. Moreover, nonlinguistic elements such as gestures, body language, and expression are needed in conveying messages directly without any accompanying speech.

Although English speaking is important, Indonesian students still face many difficulties. In terms of English skills including speaking skill, English Proficiency Index (EPI) (2015) released that Indonesia was at the $32^{\text {nd }}$ rank out of 70nationswith the score 52.91. Specifically this result showed English speaking achievement that Indonesia only on $8^{\text {th }}$ ranked out of 16 countries in Asia (EPI, 2015). Similarly, in the study done by Educational First (2013) found that the position of Indonesian learners' English speaking skill was in the moderate proficiency and the score was just 53.4. According to Richards (2006), there are four reasons why students' English speaking ability is still weak. Firstly, students lack of exercise on speaking skill. Secondly, teacher's limited English proficiency. Thirdly, students' limited opportunities to express their ideas in English. Fourthly, less of contributive factors are such as environment, friend, and family.

The study conducted by Kurniati (2011) on English speaking achievement of the eleventh grade of SMA 12 Palembang also showed that students' speaking achievement is still poor which was shown by the result of posttest score (67.5). From the facts above, teaching English speaking is still challenging for Indonesian English teachers as well as students.

In addition to speaking, English reading is also a challenge for Indonesian students. Diem and Novitasari (2012) found that English reading comprehension achievement of fifth graders in Palembang was still problematic. It was shown by the mean score of the English reading achievement test that was only 30.30 and it was below the standard score. The study conducted by Diem, Vianty, and Mirizon (2016) also found that the English Comprehension Achievement scores of 355 state junior high schools students in different state public schools in Palembang was 67.5, while the KKM (Minimum Competences Criteria) is 75.0. It also suggests that the students may get more difficulties in the reading comprehension in their later learning at senior high schools.

In relation to the focus of the study, the writer had done a preliminary investigation on the students' reading comprehension and speaking performance. The writer gave the Jennings Informal Reading Assessment test (Jennings, 2001) to the eight grade students of MTs 
Masdarul Ulum Teluk Kecapi Pemulutan. The result showed that many students are classified at Level 1 which means that the students need help in the areas of word recognition, word meaning, and comprehension. In terms of English speaking performance, the result of the observation had been conducted by the writer during the teaching and learning session four times showed that the students have limited English vocabularies, use their mother tongue then translate it into English to speak, and feel reluctant to speak.

This present study was aimed to help the English students improve their reading comprehension and speaking performance. Instructional Conversation Method was applied to improve reading comprehension and speaking performance. ICM (Instructional Conversation Method) can improve not only students' reading comprehension, but also speaking performance. Lantolf (2004, p. 35) explains that ICM in language classroom is really relevant to the process of English language learning because it exposes students into language learning based on the context of teaching and learning English. By using ICM, students can grow and develop their English language skills. The English teacher provides them opportunities to express their ideas in English.The Instructional conversation also focuses on communicative and cognitive functions of talk than current models of input, output, and interaction (IOI). McLeod (1994, p. 157) describes that instructional conversation methodis one of the best methods for developing the English language learning, which occurs best when teaching and learning process runs in the real context.

Several previous studies applied ICM to improve students' reading comprehension and speaking performance. For example, The study conducted by Yusuf (2011) who also applied ICM in teaching reading comprehension in selected junior secondary schools in Kaduna Metropolis, Northwest Nigeria showed that ICM provided students to be active in using English. The findings revealed significant differences in the performance of students taught reading comprehension using Instructional Conversation Method and those who were not.

The study done by Aidinlou and Tabeei (2012) also applied ICM and traditional method to the Iranian EFL learners in order to improve their reading comprehension achievement. The result of their study showed that the learners had a greater understanding and the learners obtained more information. The findings of the study indicated that combination of Instructional Conversation and Tradition group obtained significantly higher mean scores in comparison to instructional conversation alone.

Another study conducted by Ghaffari and Fatemi (2015) who investigated the use of Instructional Conversation Method on speaking skill of Iranian intermediate EFL learners found that instructional conversation not only developed the students' understanding of the language via interaction, but also increased their speaking abilities by interaction. 
Considering the facts that ICM can help the students' reading comprehension and speaking achievement, this present study also applied the Instructional Conversation Method in English language teaching to help the eighth-graders improve their reading comprehension and speaking performance.

\section{Review of literature}

Reading is a receptive skill that involves getting information and meaning, visual information, and written information. According to Konza (2006, p. 1), reading in English is an activity done by students to get information from many kinds of texts. Readers need to interact with the texts and try to construct the meaning of what they read. By having the English reading activity, the readers use the knowledge that they have and language skills to understand certain information. They can identify and recognize the message through each word that builds the content of the text.

Reading also means comprehending the written information. The phrase "reading comprehension" is defined as the process of making meaning from text. The purpose of it is to gain the picture of what is described in the text (Woolley, 2011, p. 15). Reading comprehension helps students acquire vocabulary and grammar. Both vocabulary and grammar help the students to build comprehensible sentences. This is in line with one of the main objectives stated in the Regulation Number 70, 2013 of teaching English reading at Junior High school in Indonesia, that is, to make students able to comprehend texts.

Instructional Conversation Method is promoted to improve reading comprehension and speaking performance. ICM (Instructional Conversation Method) can improve not only students' reading comprehension, but also speaking performance. Lantolf (2004, p. 35) explains that ICM in language classroom is really relevant to the process of English language learning because it exposes students into language learning based on the context of teaching and learning English. By using ICM, students can grow and develop their English language skills. The English teacher provides them opportunities to express their ideas in English.The Instructional conversation also focuses on communicative and cognitive functions of talk than current models of input, output, and interaction (IOI). McLeod (1994, p. 157) describes that instructional conversation methodis one of the best methods for developing the English language learning, which occurs best when teaching and learning process runs in the real context.

The study conducted by Rahman et al. (2011) who investigated the effectiveness of group discussion teaching method in the subject of social studies in Pakistan. The result of the post-test revealed that there was a significant difference in the mean score of both experimental 
and control groups. The result of the study indicated that group discussion method was more effective than lecture method.

\section{METHOD}

\section{Research Design}

This study was conducted by applying a quasi experimental research method. The pretest and posttest in the form of reading comprehension and speaking tests were administered to both experimental and control groups. The treatment was only given to the experimental group by teaching by using Instructional Conversation Method for 24 meetings.

\section{Research site and participants}

The population of the study was all of the eighth graders of MTs Masdarul UlumTeluk Kecapi Kecamatan Pemulutan in academic year 2016-2017, with the total number 115 students from four classes. Based on the result of IRI Jennings test that was given to four classes, sixty eight students from each class who have similar level where chosen as the sample. They were divided equally as the control and experimental groups.

\section{Data collection and analysis}

To collect the data, a reading comprehension test and a speaking test were given to the students The reading comprehension test consisted of fifty question items, while the speaking test required the students to retell what they had read.

Two kinds of analysis were used to answer four hypotheses in this study. First, to know whether there was a significant improvement in students' score after getting treatment, paired sample t-test was applied. Second, independent sample t-test was applied to see whether or not there was a significant difference in reading and speaking achievements between the students in the experimental and the control groups.

\section{Validity and Reliability}

For reading comprehension the writer used content validity, to make sure that the content of the reading comprehension test was relevant to the aspect of reading and syllabus of the eleventh graders. In this study, the raters were asked to check the appropriateness and to determine the level of difficulty of reading comprehension test items. The writer gave questions to the raters to check the content validity of the reading comprehension.

After the content validity of the reading comprehension test is determined based on the result of the judgment of the raters, then, to check the validity quantitatively, the writer gave them try out to students in different school. The try out was given to the eighth-grade of MTS Al Mu'awwanah Sembadak. The reading comprehension test consisted of 57 questions of five Linguists: Journal of Linguistics and Language Teaching Vol. 6, No. 1, July 2020 
grades (Level Preprimer to Level 3). After getting the valid items, Reliability of reading test was measured by using Pearson Product-Moment. A test was considered reliable if the reliability coefficient of the test was higher than 0.70 . The correlation results between rater I and II were significantly reliable since all of the correlation scores were 0.914 (pretestexperimental), 0.848 (posttest-experimental), 0.844 (pretest-control), and 0.879 (posttestcontrol), higher than 0.70 .

\section{FINDINGS AND DISCUSSION}

\section{Results of Students' Reading and Speaking Based on Categories}

As shown in Table 1, the result of posttest showed satisfying result made by the students in experimental group. Most of the students could reach the level Above Average in reading and speaking after getting the treatment. Meanwhile, the students in control group had no improvement in reading comprehension; even in speaking the posttest score was lower than the pretest.

Table 1

The Score Distribution of Reading and Speaking Test $(\mathrm{N}=43)$

\begin{tabular}{|c|c|c|c|c|c|c|c|c|c|c|}
\hline \multirow[t]{3}{*}{ Skills } & \multirow{3}{*}{$\begin{array}{l}\text { Score } \\
\text { Interval }\end{array}$} & \multirow{3}{*}{$\begin{array}{c}\text { Levelof } \\
\text { Achievement }\end{array}$} & \multicolumn{4}{|c|}{ Experimental } & \multicolumn{3}{|c|}{ Control } & \\
\hline & & & \multicolumn{2}{|c|}{ Pre } & \multicolumn{2}{|c|}{ Post } & \multicolumn{2}{|l|}{ Pre } & \multicolumn{2}{|c|}{ Post } \\
\hline & & & $\mathbf{N}$ & $\%$ & $\mathbf{N}$ & $\%$ & $\mathbf{N}$ & $\%$ & $\mathbf{N}$ & $\%$ \\
\hline \multirow{6}{*}{$\begin{array}{c}\mathbf{R} \\
\mathbf{E} \\
\mathbf{A} \\
\mathbf{D} \\
\mathbf{I} \\
\mathbf{N} \\
\mathbf{G}\end{array}$} & $86-100$ & Very good & $\mathbf{0}$ & $\mathbf{0}$ & $\mathbf{0}$ & $\mathbf{0}$ & $\mathbf{0}$ & $\mathbf{0}$ & $\mathbf{0}$ & $\mathbf{0}$ \\
\hline & $71-85$ & Good & $\mathbf{0}$ & $\mathbf{0}$ & 28 & 82 & $\mathbf{0}$ & 0 & $\mathbf{0}$ & 0 \\
\hline & $56-70$ & Average & 0 & $\mathbf{0}$ & 6 & 18 & 19 & 26 & 15 & 44 \\
\hline & $41-55$ & Poor & 12 & 35 & $\mathbf{0}$ & $\mathbf{0}$ & 15 & 44 & 19 & 56 \\
\hline & $\geq 40$ & Very poor & 22 & 65 & $\mathbf{0}$ & $\mathbf{0}$ & $\mathbf{0}$ & $\mathbf{0}$ & $\mathbf{0}$ & $\mathbf{0}$ \\
\hline & Mean & & \multicolumn{2}{|c|}{39.18} & \multicolumn{2}{|c|}{72.53} & \multicolumn{2}{|c|}{55.65} & \multicolumn{2}{|c|}{54.44} \\
\hline $\mathbf{S}$ & $86-100$ & Very good & $\mathbf{0}$ & $\mathbf{0}$ & 2 & 6 & $\mathbf{0}$ & $\mathbf{0}$ & $\mathbf{0}$ & $\mathbf{0}$ \\
\hline $\mathbf{P}$ & 71-85 & Good & $\mathbf{0}$ & $\mathbf{0}$ & 31 & 91 & $\mathbf{0}$ & $\mathbf{0}$ & $\mathbf{0}$ & $\mathbf{0}$ \\
\hline $\mathbf{E}$ & $56-70$ & Average & $\mathbf{0}$ & $\mathbf{0}$ & 1 & 3 & $\mathbf{0}$ & $\mathbf{0}$ & $\mathbf{0}$ & $\mathbf{0}$ \\
\hline $\mathbf{A}$ & $41-55$ & Poor & 3 & 9 & $\mathbf{0}$ & $\mathbf{0}$ & 31 & 91 & 28 & 82 \\
\hline K & $\geqq 40$ & Very poor & 31 & 91 & $\mathbf{0}$ & $\mathbf{0}$ & 3 & 9 & 6 & 18 \\
\hline I & Mean & & & & 79. & & 44.65 & & 44.1 & \\
\hline \multicolumn{11}{|l|}{$\mathbf{N}$} \\
\hline G & & & & & & & & & & \\
\hline
\end{tabular}

\section{Result of Students' Reading Achievement}

Table 2 presents the result of paired sample t-test which was aimed to answer the question whether or not there were significant improvements in reading comprehension and its aspects after the studentswere taught by using Instructional Conversation Method?. Table 2 also presents the result of independent sample t-test which was aimed to answer whether or not there were significant differences in reading comprehension and its aspects between the students who were taught by using Instructional Conversational Method and those who were not. 
Table 2

Results of Paired and Independent Samples t-test of Reading Comprehension and Its Aspects

\begin{tabular}{|c|c|c|c|c|c|c|c|c|c|c|}
\hline \multirow{4}{*}{ Variables } & \multicolumn{8}{|c|}{ Paired sample t-test } & \multicolumn{2}{|c|}{$\begin{array}{l}\text { Independent } \\
\text { sample t-test }\end{array}$} \\
\hline & \multicolumn{4}{|c|}{ Experimental } & \multicolumn{4}{|c|}{ Control } & \multirow{3}{*}{$\begin{array}{c}\text { Mean } \\
\text { diff }\end{array}$} & \multirow{3}{*}{ t/sig. } \\
\hline & \multicolumn{2}{|c|}{ Mean } & \multirow{2}{*}{$\begin{array}{c}\text { Mean } \\
\text { diff }\end{array}$} & \multirow[t]{2}{*}{ t/sig. } & \multicolumn{2}{|c|}{ Mean } & \multirow{2}{*}{$\begin{array}{c}\text { Mean } \\
\text { diff }\end{array}$} & \multirow[t]{2}{*}{ t/sig. } & & \\
\hline & Pre & Post & & & Pre & Post & & & & \\
\hline \multirow[t]{2}{*}{ Reading } & 33.82 & 79.00 & 45.176 & 39.64 & 44.65 & 44.18 & 4.71 & 1.244 & 34.824 & 40.320 \\
\hline & & & & 0.000 & & & & 0.222 & & 0.000 \\
\hline \multirow[t]{2}{*}{ Main Idea } & 4.00 & 9.41 & 5.412 & 16.263 & 5.18 & 5.12 & 0.059 & 0.442 & 4.294 & 12.826 \\
\hline & & & & 0.000 & & & & 0.661 & & 0.000 \\
\hline \multirow[t]{2}{*}{ Detail } & 10.88 & 25.71 & 14.824 & 13.583 & 13.41 & 13.35 & 0.59 & 0.373 & 12.353 & 22.888 \\
\hline & & & & 24.317 & & & & 0.711 & & 0.000 \\
\hline \multirow{2}{*}{$\begin{array}{c}\text { Cause and } \\
\text { Effect }\end{array}$} & 4.06 & 10.65 & 6.588 & 14.607 & 5.71 & 5.82 & 1.18 & 1.436 & 4.824 & 10.592 \\
\hline & & & & 0.000 & & & & 0.160 & & 0.000 \\
\hline \multirow{2}{*}{ Inference } & 5.35 & 12.47 & 7.118 & 16.794 & 7.76 & 7.47 & 0.294 & 1.537 & 5.000 & $\mathbf{1 3 . 4 5 5}$ \\
\hline & & & & 0.000 & & & & 0.134 & & 0.000 \\
\hline \multirow[t]{2}{*}{ Vocabulary } & 3.76 & 6.29 & 2.529 & 8.211 & 4.82 & 4.76 & 0.059 & 0.373 & 1.529 & 5.197 \\
\hline & & & & 0.000 & & & & 0.711 & & 0.000 \\
\hline \multirow[t]{2}{*}{ Sequence } & 5.76 & 14.47 & 8.706 & 17.212 & 7.76 & 7.65 & 0.118 & 1.000 & 6.824 & 14.391 \\
\hline & & & & 0.000 & & & & 0.325 & & 0.000 \\
\hline
\end{tabular}

As shown in Table 2, there were significant differences in the students' reading comprehension (total) and all its aspects between before and after they got the treatment.. However, different results showed by the control group; the students reading comprehension (total in posttest was lower than pretest, but it was not significant. The aspects of reading also improved, but they were not significant.

The result of the independent sample t-test showed a significant difference between the result of posttest in the experimental and the control groups. In addition, the aspects of reading such as main idea, detail, inference, and vocabulary also showed significant differences between in the experimental and control groups.

\section{Results of Students' Speaking Achievements}

Table 3 presents the result of paired sample t-test which was aimed to answer the question whether or not there were significant improvements in speaking performanceand its aspects after the studentswere taught by using Instructional Conversation Method. The independent sample t-test was also applied to answer whether or not there were significant differences in speaking performance and its aspects between the students who were taught by using Instructional Conversational Method and those who were not. 
Table 3

Results of Paired and Independent Samples t-Test of Speaking Achievement and Its Aspects

\begin{tabular}{|c|c|c|c|c|c|c|c|c|c|c|}
\hline \multirow{4}{*}{ Variables } & \multicolumn{8}{|c|}{ Paired sample t-test } & \multicolumn{2}{|c|}{$\begin{array}{l}\text { Independent } \\
\text { sample t-test }\end{array}$} \\
\hline & \multicolumn{4}{|c|}{ Experimental } & \multicolumn{4}{|c|}{ Control } & \multirow{3}{*}{$\begin{array}{c}\text { Mean } \\
\text { diff }\end{array}$} & \multirow{3}{*}{ t/sig. } \\
\hline & \multicolumn{2}{|c|}{ Mean } & \multirow{2}{*}{$\begin{array}{c}\text { Mean } \\
\text { diff }\end{array}$} & \multirow[t]{2}{*}{ t/sig. } & \multicolumn{2}{|c|}{ Mean } & \multirow{2}{*}{$\begin{array}{c}\text { Mean } \\
\text { diff }\end{array}$} & \multirow{2}{*}{ t/sig. } & & \\
\hline & Pre & Post & & & Pre & Post & & & & \\
\hline Speaking & 39.18 & 72.53 & 33.353 & $\begin{array}{c}26.696 \\
0.000 \\
\end{array}$ & 55.65 & 54.44 & 1.206 & $\begin{array}{l}1.011 \\
0.320\end{array}$ & 18.088 & $\begin{array}{c}16.571 \\
0.000 \\
\end{array}$ \\
\hline Pronunciation & 12.47 & 18.82 & 6.353 & $\begin{array}{l}5.260 \\
0.000\end{array}$ & 15.00 & 1482 & 0.176 & $\begin{array}{l}1.025 \\
0.675 \\
\end{array}$ & 4.000 & $\begin{array}{l}\mathbf{8 . 6 8 7} \\
\mathbf{0 . 0 0 0} \\
\end{array}$ \\
\hline Grammar & 6.79 & 18.24 & 11.441 & $\begin{array}{c}10.472 \\
0.000\end{array}$ & 13.91 & 14.09 & 0.176 & $\begin{array}{l}1.055 \\
0.772 \\
\end{array}$ & 4.147 & $\begin{array}{l}7.546 \\
0.000\end{array}$ \\
\hline Vocabulary & 9.26 & 17.82 & 8.559 & $\begin{array}{l}7.538 \\
0.000 \\
\end{array}$ & 14.79 & 13.50 & 1.294 & $\begin{array}{l}2.422 \\
0.026\end{array}$ & 4.324 & $\begin{array}{l}8.103 \\
0.000\end{array}$ \\
\hline Fluency & 10.47 & 18.65 & 8,176 & $\begin{array}{l}6.820 \\
0.000\end{array}$ & 13.26 & 13.65 & 0.382 & $\begin{array}{l}0.652 \\
0.457\end{array}$ & 5.000 & $\begin{array}{l}8.486 \\
0.000\end{array}$ \\
\hline
\end{tabular}

Table 3 shows that there were significant differences in the students' speaking and its aspects after they were taught by using the treatment. The results of the students' speaking achievement in the control group were improved, but they were not significant.

The result of the independent sample t-test for students' speaking achievement and its aspects showed a significant difference between the result of posttest in the experimental and the control groups.

\section{DISCUSSION}

First, in terms of the result of the reading comprehension test, there was a significant difference in students' achievement after getting the treatment in the experimental group. It was claimed that it was the result of the use of Instructional Conversation Method in teaching reading. Lantolf (2004, p. 35) explains that Instructional Conversation Method in the language classroom is really relevant to the process of English language learning because ICM exposes students into language learning based on the context of teaching and learning English. By using ICM, students can grow and develop their English language. The English teacher provides them opportunities to express their ideas in English. Instructional conversation is also focused on communicative and cognitive functions of talk than current models of input, output, and interaction (IOI). McLeod (1994, p. 157) describes that instructional conversation method is one of the best methods for development of the English language learning, which occurs best when teaching and learning best on the context. By using ICM, students can connect their experience, which is the same with the reading passage that they are discussing.

Second, from all aspects of reading, the aspects of reading were significantly different after the treatment. In reading activity using Instructional Conversation Method, the students were trained to get the information from English reading texts. They also could work in pair in 
order to share the information. So that, they could comprehend the information from the English reading texts which refer to the aspects of reading comprehension.

Third, in control group where the students were not given the treatments, there was no a significant difference between students' reading pretest and posttest. The mean score of pretest was higher than the posttest. It was because the students in this group did not receive any teaching as the experimental did. They were not trained how to get the important information in the comprehending English reading texts as in experimental group.

The findings also showed that the results of students' posttest in both groups were significantly different. Besides because of Instructional Conversation as one of methods that can help students comprehend texts and provide the students more opportunities to share their information. The ICM trains them to be accustomed to the reading activities and helps them to increase their reading comprehension. It is in line with what Lebedev $(2008$, p. 1) describes that the main objectives of the teaching English reading as follows: (1). Reading activates and reinforces other skills (grammar, vocabulary, pronunciation, and writing). In the same way that oral dialogues, short compositions, and listening activities do, reading can put into practice grammatical structures, new lexical items, and elements of pronunciation. Reading can also offer good writing models. Similarly, Seifert (2017, p. 1) adds that Reading enhances other essential ESL skills like speaking, listening, and writing. (2). Reading becomes a better reader. Reading is a skill in itself, and the advantage of working with adult language learners is that they are usually literate in their native language. This means that they are able to transfer advanced reading skills to the second language classroom. Reading in English can activate and develop these skills, making the students better readers in both languages. Reading skills include: skimming, scanning, predicting, and reading for detailed comprehension.

In terms of speaking, the students' speaking achievement of pretest and posttest in the experimental group were significantly different, while in the control group, there was no significant. It might because of the influence of using Instructional Conversation Method. According to Yusuf (2011), in using Instructional Conversation Method, teachers should make sure that they set clear academic goals that guide the conversation with students in class. Teachers should ensure students have more time to talk. As much as possible, teachers should encourage all students to participate actively in class conversation. Teachers should always consider the characteristics of learners, their background experiences and psycho-social factors as well as other pedagogical issues. There is a need for teachers to always stimulate students' existing knowledge in order to make them relate their background knowledge to the text. The use of instructional conversation method would help teachers to engage their students in purposeful conversation/dialogue. Such purposeful conversation could assist students in providing relevant information needed for the comprehension of the text.

Linguists: Journal of Linguistics and Language Teaching

Vol. 6, No. 1, July 2020 
Finally, related to the results of paired sample t-test, the result of independent sample ttest also showed that students' speaking posttest in both groups were significantly different, so were all of the aspects. Based on the benefits of using Instructional Conversation Method, it is clear that the results in experimental group would be better that the control one. The control group, who did not get any treatment, was not trained how to retell the text fluently, use the appropriate vocabularies and grammar, and use the correct pronunciation. That was the reason why the result of control group was not so good as experimental group.

To sum up, because of its advantages, the used of Instructional Conversation Method was effective to help the students in improving their reading comprehension and speaking achievements. Through the use of ICM, the students can get interesting method for their reading and speaking activities; so that they can be more motivated learning and their reading comprehension can be improved. Then, since they can read before they speak English, they can get idea in speaking; also they can get much information. It means Instructional Conversation Method not only improve their reading comprehension, but also their speaking achievement.

\section{CONCLUSION}

Based on the interpretations, using Instructional Conversation Method has successfully improved the students' reading comprehension and speaking performance in total. The students' in experimental group outperformed the control group both reading comprehension and speaking. The aspects of reading have improved from pretest to posttest. The aspects that improve were main idea, detail, cause and effect, inference, vocabulary, and sequence. While in speaking, all of the aspects showed a significant improvement from pretest and posttest after being taught by using ICM. Then, being compared to the control group who did not get the treatment, the result showed that there were a significant difference of students' reading and speaking posttest results.

Furthermore, there are some suggestions that can be offered as the follow up of this study. First, in determining the reading material, the teachers should consider the students' reading comprehension level, so that the activity can be in line with the objective, to help the students' improving their reading comprehension. Second, in the classroom activity, the teacher should help the students to improve their ability in every aspect. In speaking for example, besides giving the students time to share their idea to others, the teacher should also help them to comprehend texts with appropriate word choices, correct pronunciation, grammar, and fluency. Third, to get the best result of using ICM in the classroom, the availability of English reading material and good motivation to speak English is required. Last, to maximize the result 
of using ICM, the students' ability must be considered, so those who are better can help the member of the group whose ability is low.

\section{REFERENCES}

Aidinlou, N, A., \& Tabeei, S. (2012). The effect of using instructional conversation method on reading comprehension of Iranian EFL learners. I.J. Modern Education and Computer Science, 9, 45-51.

Diem, C.D. \&Novitasari, R. (2012). Exploring online resources for/with fifthgraders to cultivate reading habits and increase English literacyachievement. Basic Research Journal of Education Research andReview, 1(3), 38-47.

Diem, C.D., Vianty, M., \& Mirizon, S. (2016). Students' specific comprehension skills in English based on locations, grades, and gender. A paper to be presented at AARE International Conference Melbourne, Australia, November 28 to December 1, 2016.

Education First.(2013). Retrieved from http://www.ef.co.id/epi. English Proficiency Index. (2014). English proficiency in profile. Retrieved from http://www.ef.co.id// /media/centralefcom/epi/v4/downloads/full-report s/ef-epi2014-indonesia.pdf

Ghaffari, S. \& Fatemi, M, A (2015). The effect of using instructional conversation method on speaking skill of Iranian intermediate EFL learners. International Journal of Language Learning and Applied Linguistics World, 4(10), 1-13.

Jennings, J. (2001). Jennings informal reading assessment. Retrieved from http://wps.ablongman.com.

Konza, D. (2016). Teaching children with reading difficulties. South Melbourne, Vic: Thomson Social Science Press.

Kurniati, (2011).Improving the speaking skill of the eleventh grade students of SMA Negeri 12 Palembang through Australiasm Parliamentary debate Technique (Unpublished Master's Thesis).Sriwijaya University, South Sumatera, Indonesia.

Lantolf, J, P. (2004). Sociocultural theory and second language learning. Oxford: Oxford University Press.

Lebedev, J, R. (2008). Four objectives of reading in the ESL classroom. Retrieved from https://englishwithjennifer.wordpress.com/2008/11/14/four-objectives-of-reading-inthe-esl-classroom/

McLeod, B. (1994). Language and learning: Educating linguistically diverse students. New York, NY: State University of New York Press.

Renandya, W. A. 2004. Indonesia. In H. W. Kam\& R. Y. L. Wong (Eds.), Language policies and Language education: The impact in East Asian countries in the next decade (pp.115-131). Singapore: Eastern University Press.

Rahman, F., Jumani, N. B., Ajmal, M., Malik, S., \& Sharif, M. 92011). Impact of discussion method on students' performance. International Journal of Business and Social Science, 2(7), 533-35.

Richards. S. (2006). The effects of high-structure cooperative versus low-structure collaborative design on online debate in term of decision making, critical thinking, and interaction pattern. Dissertation Abstractc International,64(10), 3652.Retrieved from www.professorjackrichards.com. 
Richards, J. C., \&Renandya, W. A. (2002).Methodology in language teaching:An analogy of current practice.Cambridge: Cambriedge University.

Seifert, S. (2017).6 super strategies for improving ESL reading comprehension for biginners. Retreived from http://www.fluentu.com/english/educator/blog/esl-readingcomprehension-for-beginners/

Woolley, G. (2011). Reading comprehension: Assisting children with learning difficulties. New York, NY: Springer Science+Business Media.

Yusuf, H. (2011). The effect of using instructional conversation method in teaching reading comprehension in selected junior secondary schools in Kaduna Metropolis. Journal of Language Teaching and Research, 1(2), 55-59. 